\title{
Perceptual and behavioural dimensions: measuring brand equity consumer based
}

Paula Rodrigues

\author{
Management Department, Lusiada University, Porto, Portugal, and \\ Francisco Vitorino Martins \\ Faculty of Economics, University of Porto, Porto, Portugal
}

\begin{abstract}
Purpose - The purpose of this paper is to propose a brand equity measurement model in the consumers' mind. The measurement model separates the perceptual component of the behaviour component of individuals in their preferences for brands. That is, as a result of a set of perceptions, consumers create a brand equity that will be realised in loyal behaviour and in their willingness to pay a premium price for a brand.

Design/methodology/approach - A measurement model of brand equity using the methodology of SEM is proposed. Two samples were used, one for the estimation and another one for the validation of the proposed model, with 272 observations each. The sample is constituted by consumers of five denim clothing brands that have their own chain of stores in Portugal.

Findings - Results show that the model is statistically valid and that perceptual aspects should be separated from behavioural aspects in brand equity measurement based on consumers' mind.

Originality/value - The originality of the model is the division of constructs into perceptual constructs (inputs), and of behaviour constructs (outputs) of brand equity. By doing this, the model tries to answer two important aspects of entrepreneurial management: which are the explanatory variables of brand equity and how could that be translated into an answer, for the consumer.
\end{abstract}

Keywords Brand equity, Entrepreneurial management, Consumer behaviour, Portugal,

Structural equations modelling

Paper type Research paper

\section{Introduction}

In global markets, brands are important in achieving good results in business. Knowing what leads consumers to prefer certain brands could be primordial in the development of business strategies, in order to obtain loyal consumers who are willing to pay more for a branded product. This work enables to have a more in-depth understanding of the antecedents of brand equity and its determinants, as well as the development of an improved instrument to measure brand equity.

The research on brand equity has been inserted in cognitive psychology and centred in the analysis of cognitive processes of the consumer. In this field, two principal issues are considered for the analysis of brand equity (Irmscher, 1993; Barwise, 1993; Chaudhuri, 1995; Feldwick, 1996) - the first one is that brand equity is equivalent to the multidimensional construction of the knowledge of the brand (Keller, 1993) and the second one, headed by the works of Aaker $(1991,1996)$, considers brand equity like a multidimensional construction integrated into a series of assets and liabilities that add value to the brand, for the company and for the consumer. The problem of validity of content around brand equity is not solved yet, given the diversity of operative descriptions that we can found about it (Aaker, 1991; Keller, 1993; Farquhar, 1989; Park and Srinivasan, 1994; Rangaswamy et al., 1993; Lassar et al., 1995; Kapferer, 1997; 
JFMM

20,4

508

Motameni and Shahrokhi, 1998; Dawar and Pillutla, 2000; Yoo et al., 2000; Faircloth et al., 2001; Vázquez et al., 2002; Stahl et al., 2012; Buil et al., 2013).

The subject of brand equity measurement has attracted the attention of academic and business community due to the strategic importance of brand management in companies. Keller and Lehmann (2003) delineate three approaches for assessing brand equity: customer mindset (Aaker, 1996; Keller, 2008), product market (Park and Srinivasan, 1994) and financial market (Mahajan et al., 1994). These approaches have different strengths and weaknesses (Ailawadi et al., 2003). In this paper, brand equity is measured based on the consumer perspective and the constructs and scales of its measurement are analysed. In this work, the brand equity is considered as a multidimensional construction of the knowledge of the brand (Keller, 1993), according to a construction approach in the consumer's mind (Keller, 2008) and in a holistic view of brand management.

In this study, the main goal is to propose a measurement model in brand equity in the consumers' mind, which follows the perspective of considering the brand as an intangible asset that has associated a certain capital, which is the result of perceptions and attitudes, towards brands which give them a value. The measurement model of brand equity based on consumers' mind separates the perceptual component of the behavioural component of individuals in their preferences for brands. That is, as a result of a set of perceptions, consumers create a brand equity that will be realised in their loyal behaviour and in their willingness to pay a premium price for a brand.

The separation of the antecedents and consequences of brand equity is relevant to a better brand management at the enterprise level. Thus, in the case of denim brands, it is considered that a brand has value when it has high brand awareness; consumers perceive the brand as a brand of high quality and have a suitable personality with the consumer. In turn, the consumer to recognise the brand equity is willing to pay more for the brand and to be loyal. The brand awareness is considered a major construct of brand equity (Keller, 1993; Netemeyer et al., 2004) and as such should be considered a measure model. In the most customer-based brand equity framework (Aaker, 1991; Keller, 1993) perceived quality is considered a primary construct. The main reason that perceived quality is an important construct in brand equity models is that it has a strategic effect on brand equity, by reducing the perceived risk and allowing differentiation and brand extension. The perceived quality absorbs the most relevant functional aspects in the consumer's mind to face what he expects of a brand. The most relevant aspect of the proposed theoretical model has to do with the consideration of the personality of the brand as a key construct in creating brand equity. The brand personality covers the different and intangible aspects that denim brands have in the consumers' minds (Aaker, 1997; Ang and Lim, 2006).

Unlike most of the models proposed to explain brand equity in the minds of consumers (Aaker, 1991; Keller, 1993; Yoo et al., 2000), this model considers the brand loyalty as a result of the recognition of brand equity. How customers perceive brands and what motivates them to pay a price premium is an important theme on brand equity research. Customer-based brand equity has often been defined as synonymous with price premium (Ailawadi et al., 2003). Premium price reflects the brand's ability to command a higher price in the competitive market (Villarejo-Ramos and Sánchez-Franco, 2005).

The work is structured as follows: a literature review, development of theoretical model and research hypotheses, the methodology, results and discussion, conclusion and presented limitations, implications for the management and future developments. 


\section{Theoretical background}

The meaning of brand equity has been the object of a large discussion from the part of several authors (Ambler and Sytles, 1995; Chaudhuri, 1995; Feldwick, 1996). According to Agarwal and Rao (1996) and Erdem and Swait (1998) one unanimous definition of brand equity has not been arrived at and this question still remains. However, some agreement exists on what concerns the fact that brand equity must be studied from different perspectives, in a vision that emphasises complementarities, and not competition (Irmscher, 1993; Czellar, 1997; Erdem and Swait, 1998), towards understanding the complexities of consumer behaviour.

Consumer-based brand equity knowledge has evolved from two paradigms: one from cognitive psychology and the other from the theory of signalling economic information (Czellar and Dennis, 2002). However, dominant research centralises in cognitive psychology, focussed more precisely on memory structure (Aaker, 1991; Keller, 1993; Biel, 1993; Low and Lamb, 2000; Pappu et al., 2005; Yoo and Donthu, 2001; Crimmins, 2003).

Based on cognitive psychology there are many definitions of the concept of brand equity and there are many methods proposed for its measurement. Nevertheless, for measuring brand equity it is necessary to start by defining the concept. There are numerous definitions of brand equity concept, proposed by different authors (Leuthesser, 1988; Srivastava and Shocker, 1991; Simon and Sullivan, 1993; Blackston, 1995; Calderón et al., 1997; Yoo and Donthu, 2002; Amraoui and Morales, 2006).

In this study, we assume that brand equity is understood as a multidimensional construction perceived by consumers, which adds capital to the product which has a brand and allows the company to have more loyal consumers and practice enhanced prices. This concept of brand equity makes a distinction between perceptual and behavioural aspects of the consumer.

The proposed model has three logical moments of analysis: the antecedents of brand equity, the brand equity in itself and its consequences, the ones considered as a final result, with an interest in the management of companies and brands (Figure 1).

In reference for the brand equity, this study proposes antecedents and consequences. On one hand, perceptual dimensions (brand awareness, perceived quality and brand personality) - that determine the brand equity in the consumers' mind are considered; on the other hand, behavioural dimensions (brand loyalty and willingness to pay a premium price) - that are the reaction of the capital attributed to the brand are considered.

Brand equity is a perceptual construction, a perception of consumers, which adds value to a branded product. In this variable all influences mix, positives and negatives, and this makes possible to award a certain value to the brand. The value attributed by the consumer to a brand reflects his awareness, and the opinion about the quality and personality of the brand.

On one hand, it could be considered that the consumer involved with a brand, through brand awareness, perceived quality and brand personality would have a determined type of behaviour resulting from the equity of the brand. In this way, the presented model sees as the final effect the component behaviour, where two variables (constructs) are admitted. These variables (constructs) are the result of the importance of brand equity - loyalty to the brand and willingness to pay a higher price for it.

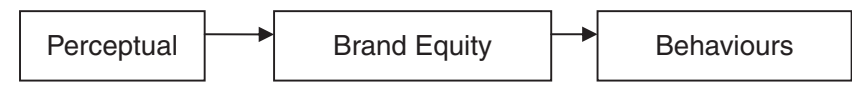

Figure 1. Brand equity model components 
JFMM

20,4

510

\section{Research model and hypothesis}

The model of structural equations proposed contains latent variable (constructs), measured by a joint of scales (items). Data were collected through a questionnaire addressed to consumers of the brands under study. Then, we analysed the concept of each of the latent variables, such as relationships between them that could place them as research hypothesis (Figure 2).

Brand awareness refers to the capacity of the consumer to remember and recognise the brand (Keller, 1993; Netemeyer et al., 2004; Yoo et al., 2000; Yoo and Donthu, 2001). Awareness affects the perceptions the consumer has about the brand, contributing to the perceptual evaluation, that is, expressed on brand equity. A brand with a large remembrance leads to an increase of perceptual brand equity in consumers' minds:

H1. There is a positive relationship between awareness and brand equity from the point of view of the consumer.

The latent variable of the perceived quality concerns the subjective evaluation of the quality of the product, in agreement with the classic definition of Zeithaml (1988) and Aaker (1991) also followed by Yoo et al. (2000) and Yoo and Donthu (2001). In the proposed model, perceived quality is seen as a subjective evaluation made by the consumer about the brand and, being so, it affects the formation of brand equity. A consumer who associates the brand with a certain quality is in conditions of attributing a higher value capital to the brand:

H2. There is a positive relationship between perceived quality and brand equity from the point of view of the consumer.

Brand personality is an explanatory variable of the perceptual evaluation of brand equity by the consumer. It assumes that the consumer chooses a brand in order to express his own image (self-extended). For that, he evaluates positively the brand that has a personality similar to his own personality (Aaker, 1997; Aaker et al., 2004; Phau and Lau, 2001; Ang and Lim, 2006). In this way, the brand personality may be directly linked to the construction of brand equity:

H3. There is a positive relationship between brand personality and brand equity from the point of view of the consumer.

Figure 2.

Structural model

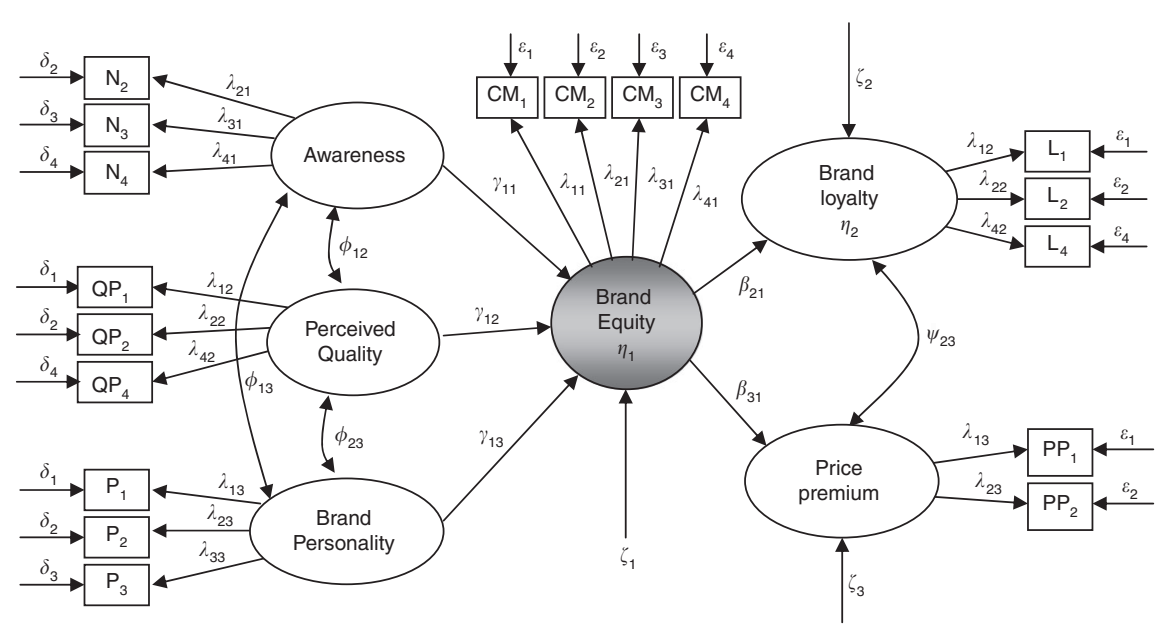


Besides analysing factors that contribute for the construction of brand equity from the part of the consumer, this hypothesis claims that brand equity may lead to a certain consumer behaviour. Therefore, it is considered as it may allow the analysis of how far brand equity influences consumer loyalty and his willingness to pay a higher price for a branded product.

Brand loyalty in the proposed model is a perceptual loyalty, that is, to say the result of the evaluation the consumer does when in selecting a brand is the result of a positive perceptual evaluation strong enough to lead him to a loyalty behaviour. A favourable evaluation of brand equity may lead to the preference and purchase of the branded products for a long time (Odin et al., 2001; Oliver, 1997, 1999; Chaudhuri and Holbrook, 2001; Back, 2005; Kuikka and Laukkanen, 2012). Attitude constituents and behaviours are both present in this construct:

H4. There is a positive relationship between brand equity and brand loyalty from the point of view of the consumer.

The consumer is willing to pay a higher price for a certain brand if this brand has a high brand equity (Ailawadi et al., 2003; Villarejo-Ramos and Sánchez-Franco, 2005; Netemeyer et al., 2004). That willingness to pay a higher price results from the consumer's understanding that the brand confers a set of superior benefits in relation to others. The proposed model takes this into account, considering that a direct relationship exists between brand equity and the willingness to pay a higher price:

H5. There is a positive relationship between brand equity and the willingness to pay a price premium from the point of view of the consumer.

The proposed variables are constructs, that is, to say, they are theoretical concepts that are not observed directly, and consequently the clarification of dimensions and scales used is needed. Therefore we make a review of the literature about scales used to measure several perceptual constructs and behaviours and relate them to the proposed model. We start with the review of the literature where some scales are used to measure theoretical constructs. This approach has the clear advantage of using constructions and scales already validated in the scientific literature, but some adaptation and analysis of reliability is needed.

\section{Methodology}

The populations under study are clothing consumers and visitants of five brands which have their own retailing chain. The consumers who answered the questionnaire in the stores were distributed randomly into two groups of data, one used in the estimation of the models (and they are designed as the sample survey) and the other used as a validation sample, carrying out the methodological requirements. In the research a structured questionnaire was used with scales of Likert of five points. The questionnaire was divided into two big sections. The first one contains a series of questions about the characteristics of consumers and the second one has the questions related to the variables of the model and the objectives of research.

In terms of the field work it was necessary to identify clothing brands that could be the object of analysis. Brand selection was made based on a pretest prepared in a university environment, during October and November 2014, with a sample of 65 students, evaluating the spontaneous reputation of the brands. The students were asked to refer the brands of denim clothing they knew which had their own stores. The brands mentioned were Levi's, Salsa, Pepe Jeans, Tiffosi and Diesel.
Perceptual

and

behavioural

dimensions 
JFMM 20,4
In this study, the sample selection was made in the moment of data collection, because we are dealing with individuals - potential buyers - that came into the stores of all different brands considered in the study and who accepted to answer the questionnaire. In this way, we deal with a convenience sample, in spite of the feel that we did not control who really went to the store. The inquiry in the point of sale was the option, because there was no list of consumers with telephonic contacts or addresses. Data collection was made since mid-March 2015 and during all month of April of the same year. The inquiry proceeding inside the stores was completely random, approaching the consumer at the exit of the store, independent of who has shopped anything. We obtained 544 valid questionnaires.

Modelling through structural equations has been used often in social sciences, so it is a well-known confirmatory method. This method provides an understanding of the makes possible for the research in an environment that evaluates and changes theoretical models (Hair et al., 2006); therefore, it has a good potential for the development of theories.

\section{Model estimation and results discussion}

With the proposed model we wanted to test the hypothesis that there exists a positive relationship between awareness and brand equity from the point of view of the consumer $(H 1)\left(\gamma_{11}>0\right)$; that a positive relationship exists between the perceived quality and brand equity from the point of view of the consumer $(H 2)\left(\gamma_{12}>0\right)$; that a positive relationship exists between brand personality and brand equity from the point of view of the consumer $(H 3)\left(\gamma_{13}>0\right)$; that a positive relationship exists between brand equity and brand loyalty from the consumer point of view $(H 4)\left(\beta_{21}>0\right)$; and, finally, that there exists a positive relationship between brand equity and the willingness to pay a price premium for the brand from the consumer point of view $(H 5)\left(\beta_{31}>0\right)$.

In this study, we follow the assumption of Anderson and Gerbing (1982) that the modelling of structural equations must be done through two conceptually distinct models: factor analysis or confirmatory measurement model and the structural confirmatory model or structural model. Following this recommendation we made an exploratory factor analysis to the set of initial indicators of constructs. From the results obtained, there were cases where it was necessary to proceed to some adjustments, mainly in the scale of brand personality. This construct was measured through many dimensions and from this large set of items it was necessary to adapt some, for the particular case of denim brand clothing and for Portuguese consumers. So, it was verified that, concerning brand personality, only one of the proposed dimensions by Jennifer Aaker (1997) had importance for Portuguese consumer in the domain of denim brands clothing: genuine dimension. Brand awareness, perceived quality and brand loyalty were measured with three items adopted from the works of Yoo et al. (2000). Brand equity was measured with four items from the same authors. Premium price was measured with three items adopted from the works of Netemeyer et al. (2004).

All other scales had little adjustments in the number of items. Eliminated items were those who presented a loading factor inferior to 0.75 . In this way, one item was eliminated from the awareness scale that was initially composed of four. The scale of perceived quality maintained the three items, and the same applied to the loyalty scale. The only one which did not suffer any adjustments was the brand equity scale, which presented always good indicators and the one of the price premium which included only two items. 
Then an analysis of scale reliability was carried out. The most followed recommendation concerning the values of reliability indicators is that of Nunnally (1978). All the constructs used in the proposed structural models present values of the Cronbach' $\alpha$ coefficient above 0.8 , except for the one of perceived quality, which nevertheless has an approximated value of 0.8 . So, it was verified that the items used to measure the constructs to be applied on models were inside the recommended values.

The results of confirmatory factor analysis (Table I) of the proposed model are presented in the next table and serve to determine the items that each construct must have and must be used in the estimation of the models in their structural form.

To analyse the goodness-of-fit (GFI), the chosen indicators are the ones suggested by Hair et al. (2006) as being the better absolute indicators about GFI, $\chi^{2}$, RMSEA, GFI, CFI and IFI. In the model of estimated measure by confirmatory factor analysis, values above 0.9 were obtained leading to the conclusion that it had a good adjustment.

After stabilisation of the model of measurement and the analysis of the quality of adjustment, we verified whether the hypotheses of research were confirmed or not. In the case of the model proposed, estimation was carried by the method of maximum likelihood (ML), so that we could meet the objective of developing and testing the theory about the measurement of brand equity based on consumers' mind.

Before moving forward with the presentation and analysis of the results it is necessary to explain some behaviours that were made at this point and that have to do with some infractions of hypothesis that are implicit to the methodology of structural equations. One of this hypotheses is related to the normality of the data. An analysis of normality of data has been carried out; skewness and kurtosis indicators have been calculated, and it can be noticed that the data did not follow a

\begin{tabular}{|c|c|c|c|c|c|c|}
\hline \multirow[b]{2}{*}{ Construct } & \multirow[b]{2}{*}{ Item } & \multicolumn{2}{|c|}{ Convergent validity } & \multicolumn{3}{|c|}{ Reliability } \\
\hline & & Factor loadings & Loading average & Cronbach's $\alpha$ & $\mathrm{CR}$ & $\mathrm{AVE}$ \\
\hline \multirow[t]{3}{*}{ Brand awareness } & $\mathrm{N}_{2}$ & $0.821^{*}$ & \multirow[t]{3}{*}{0.849} & \multirow[t]{3}{*}{0.815354} & \multirow[t]{3}{*}{0.89} & \multirow[t]{3}{*}{0.79} \\
\hline & $\mathrm{N}_{3}$ & $0.871^{*}$ & & & & \\
\hline & $\mathrm{N}_{4}$ & $0.856^{*}$ & & & & \\
\hline \multirow[t]{3}{*}{ Perceived quality } & $\mathrm{QP}_{1}$ & $0.803^{*}$ & \multirow[t]{3}{*}{0.766} & \multirow[t]{3}{*}{0.780648} & \multirow[t]{3}{*}{0.87} & \multirow[t]{3}{*}{0.78} \\
\hline & $\mathrm{QP}_{3}$ & $0.777^{*}$ & & & & \\
\hline & $\mathrm{QP}_{4}$ & $0.718^{*}$ & & & & \\
\hline \multirow{3}{*}{ Brand personality } & $\mathrm{P}_{1}$ & $0.727^{*}$ & \multirow{3}{*}{0.765} & \multirow{3}{*}{0.936546} & \multirow[t]{3}{*}{0.86} & \multirow[t]{3}{*}{0.74} \\
\hline & $\mathrm{P}_{2}$ & $0.789 *$ & & & & \\
\hline & $\mathrm{P}_{3}$ & $0.781^{*}$ & & & & \\
\hline \multirow[t]{4}{*}{ Brand equity } & $\mathrm{CM}_{1}$ & $0.888^{*}$ & \multirow[t]{4}{*}{0.880} & \multirow[t]{4}{*}{0.910221} & \multirow[t]{4}{*}{0.93} & \multirow[t]{4}{*}{0.87} \\
\hline & $\mathrm{CM}_{2}$ & $0.919 *$ & & & & \\
\hline & $\mathrm{CM}_{3}$ & $0.972^{*}$ & & & & \\
\hline & $\mathrm{CM}_{4}$ & $0.742 *$ & & & & \\
\hline \multirow[t]{3}{*}{ Brand loyalty } & $\mathrm{L}_{1}$ & $0.969 *$ & \multirow[t]{3}{*}{0.970} & \multirow[t]{3}{*}{0.917189} & \multirow[t]{3}{*}{0.91} & \multirow[t]{3}{*}{0.84} \\
\hline & $\mathrm{L}_{2}$ & $0.987^{*}$ & & & & \\
\hline & $\mathrm{L}_{4}$ & $0.956^{*}$ & & & & \\
\hline \multirow[t]{4}{*}{ Premium price } & $\mathrm{PP}_{1}$ & $0.995^{*}$ & 0.959 & 0.912654 & 0.88 & 0.81 \\
\hline & $\mathrm{PP}_{2}$ & $0.923^{*}$ & \multirow{2}{*}{\multicolumn{4}{|c|}{ Goodness-of-fit indexes }} \\
\hline & & & & & & \\
\hline & & RMSEA & GFI & AGFI & CFI & IFI \\
\hline Normalised $\chi^{2}$ & 1.69869 & 0.052 & 0.922 & 0.901 & 0.912 & 0.9 \\
\hline
\end{tabular}

Notes: CR, composite reliability; AVE, average variance extracted. ${ }^{*} p<0.001$
Perceptual and

behavioural dimensions

513 . 
JFMM

20,4

514

normal distribution. However, according to Bollen (1989), in this kind of methodology, in spite of the fact that multivariate normality is required, it is not a necessary condition for the estimation of theoretical models. Browne and Shapiro (1988) identify several conditions under which the majority of the properties of estimators of ML continue to be verified even when the data did not follow one normal multivariate distribution. So, we present and discuss the results of the proposed models estimated, immediately (Table II).

Brand awareness appears to be estimated in the model with a negative sign, that is, the bigger the notoriety the smaller the brand equity. This hypothesis is opposite to the logic of the explanatory model of brand equity. Nevertheless, it was considered the possibility that brand awareness was an initial point for the explanation of the perception of brand equity that comes from the part of the consumer, that is, every respondent knew well the brand, what is reinforced by the fact that data collection had been made in the brand stores; so, the question of brand awareness lost relevance for the explanation of brand equity. To notice that even with the negative coefficient, brand awareness could be explained for the tendency to multicollinearity, and therefore awareness may be strongly related to other perceptual constructs. In this way, the model was re-estimated without the construct "Brand Awareness" presenting indicators of better adjustments, or the GFI or the adjusted goodness-of-fit (AGFI). Take notice that the estimated coefficient of the variable quality received an important alteration, what confirms the tendency of multicollinearity.

In respect to the second hypothesis the correlation of the constructs of perceived quality and brand personality and brand loyalty and the price premium are also supported. The analysis of quality indicators of adjustment shows that the model present values for all of them, leading to the conclusion that a good adjustment is verified (Table III).

Validation of the models with a new sample is the proceeding recommended by several authors (Peterson, 1994; Anderson and Gerbing, 1982; Diamantopoulos and Siguaw, 2000; Bollen, 1989), in order to verify whether the proposed models may or may

\begin{tabular}{lcrrr}
\hline & Parameter & Estimated & p-value & Conclusion \\
\hline Main hypotheses & & & & \\
Brand awareness $\rightarrow$ brand equity (+) & $\gamma_{11}$ & -0.207 & 0.004 & Not sup. \\
Perceived quality $\rightarrow$ brand equity (+) & $\gamma_{12}$ & 0.562 & 0.000 & Supported \\
Brand personality $\rightarrow$ brand equity (+) & $\gamma_{13}$ & 0.157 & 0.009 & Supported \\
Brand equity $\rightarrow$ brand loyalty (+) & $\beta_{21}$ & 0.933 & 0.000 & Supported \\
Brand equity $\rightarrow$ price premium (+) & $\beta_{31}$ & 0.849 & 0.000 & Supported \\
Others hypotheses & & & & \\
Brand awareness $\leftrightarrow$ perceived quality (+) & $\phi_{12}$ & 0.638 & 0.000 & Supported \\
Perceived quality $\leftrightarrow$ brand personality (+) & $\phi_{23}$ & 0.558 & 0.000 & Supported \\
Brand awareness $\leftrightarrow$ brand personality (+) & $\phi_{13}$ & 0.408 & 0.000 & Supported \\
Brand loyalty $\leftrightarrow$ price premium (+) & $\psi_{23}$ & 0.482 & 0.000 & Supported \\
Indicators of adjustment & & & & \\
$\chi^{2}$ normalised & 2.062 & & & \\
RMSEA & 0.063 & & & \\
GFI & 0.906 & & & \\
AGFI & 0.869 & & & \\
\end{tabular}

Table II.

Structural model estimated
Main hypotheses

Brand awareness $\rightarrow$ brand equity $(+)$

Perceived quality $\rightarrow$ brand equity $(+$

Brand personality $\rightarrow$ brand equity $(+$

Brand equity $\rightarrow$ brand loyalty $(+)$

Others hypotheses

Brand awareness $\leftrightarrow$ perceived quality $(+$

Perceived quality $\leftrightarrow$ brand personality $(+$

Brand awareness $\leftrightarrow$ brand personality $(+)$

$\chi^{2}$ normalised

GFI

0.906

0.869 


\begin{tabular}{|c|c|c|c|c|c|}
\hline & Parameter & Estimated & $p$-value & Conclusion & Perceptus \\
\hline \multicolumn{5}{|l|}{ Main hypotheses } & behavioura \\
\hline Perceived quality $\rightarrow$ brand equity $(+)$ & $\gamma_{12}$ & 0.438 & 0.000 & Supported & \\
\hline Brand personality $\rightarrow$ brand equity ( + ) & $\gamma_{13}$ & 0.143 & 0.018 & Supported & dimension \\
\hline Brand equity $\rightarrow$ brand loyalty $(+)$ & $\beta_{21}$ & 0.932 & 0.000 & Supported & \\
\hline Brand equity $\rightarrow$ price premium $(+)$ & $\beta_{31}$ & 0.848 & 0.000 & Supported & 515 \\
\hline \multicolumn{6}{|l|}{ Others hypotheses } \\
\hline Perceived quality $\leftrightarrow$ brand personality $(+)$ & $\phi_{23}$ & 0.558 & 0.000 & Supported & \\
\hline Brand loyalty $\leftrightarrow$ price premium $(+)$ & $\psi_{23}$ & 0.508 & 0.000 & Supported & \\
\hline \multicolumn{6}{|l|}{ Indicators of adjustment } \\
\hline$\chi^{2}$ normalised & 2.249 & & & & \\
\hline RMSEA & 0.066 & & & & Table III. \\
\hline GFI & 0.919 & & & & Structural model \\
\hline AGFI & 0.881 & & & & re-estimated \\
\hline
\end{tabular}

not be generalised. Thus, the model was estimated again using the second sample, the validation sample (Table IV).

In this case, all hypotheses are supported and the indicators improve a little, in the same way verified with the first sample.

\section{Conclusions}

Modern marketing theory and practices have recognised the brand equity paradigm as a key asset for any business. Academic discussion is inconclusive about the conceptual foundations, sources and measures of brand equity. The model used here proposes the separation of constructs associated with brand equity, attending to its logical function and also with the advantages that could remove to the level of management from that different logical positioning. Thus an important empirical result was the conclusion that loyalty and willingness to pay for a price premium variable are consequences of brand equity. In the model, logical and structurally determinants of brand equity were identified, and then revealed to be statistically significant: perceived quality and brand

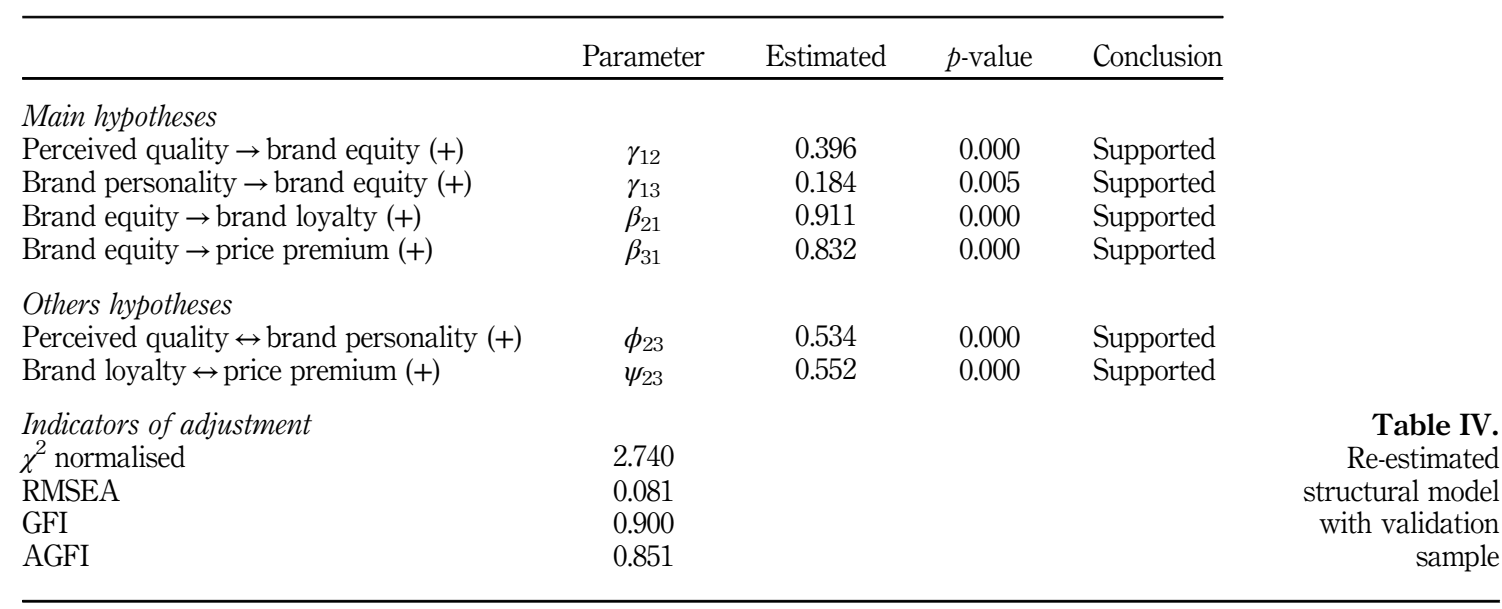


JFMM 20,4 personality. Notice that the construct brand awareness, used in measurement models of brand equity, was not important here. First, because that are brands of general knowledge and second, because the inquiry was made to potential buyers, that were inside the stores. This awareness was ensured by all respondents, not contributing (given the absence of variability) for the explanation of the different values of brand equity. Third, some empirical results describe situations of statistical instability, developing from the described situation. On the other hand, perceptual dimensions explanatory's of brand equity had a good functioning in the sense that they capture the evaluation made by consumers about the brands under study.

Businesses face challenges managing both consumers' switching behaviours and their brand portfolios. In conclusion, we could say that it is of interest to separate the constructs between antecedents and consequents of brand equity, and that this should be considered in measurement models of brand equity from consumers' perspective.

\section{Limitations, future research and managerial implications}

The research on brand equity continues to be fragmented. The contribution of the study concerns refining the general theory on brand equity, as well as developing a conceptual framework for understanding of how to have loyal customers who are willing to pay a premium price of denim brands.

This work may be improved in order to be applied to a random sample and a representative sample of consumers in general. Future research should first of all focus on validating the structure of the framework. It could be applied to other brands from different sectors to verify if the results could be and should be generalised.

Future research should be conducted in order to develop competing models so that the perceptual evaluation that consumers made about the brands is simplified. To keep the logical separation of the constructs according to its perceptual and behavioural character seems to be a good methodological clue. However, models whose behavioural components could be developed could include image effects of the stores.

The results of this paper have several managerial implications for the denim brands. Marketers should remember that there are some dimensions that influence the consumer's perception towards brand equity: perceived quality and brand personality.

\section{References}

Aaker, D.A. (1991), Managing Brand Equity: Capitalizing on the Value of a Brand Name, Free Press, New York, NY.

Aaker, D.A. (1996), Building Strong Brands, Free Press, New York, NY.

Aaker, J.L. (1997), "Dimensions of brand personality", Journal of Marketing Research, Vol. 34 No. 3, pp. 347-356.

Aaker, J.L., Fournier, S. and Brasel, S.A. (2004), “Why good brands do bad?”, Journal of Consumer Research, Vol. 31 No. 1, pp. 1-16.

Agarwal, M.K. and Rao, V.R. (1996), “An empirical comparison of consumer-based measures of brand equity”, Marketing Letters, Vol. 7 No. 3, pp. 237-247.

Ailawadi, K.L., Lehmann, D.R. and Neslin, S.A. (2003), "Revenue premium as an outcome measure of brand equity", Journal of Marketing, Vol. 67 No. 4, pp. 1-17.

Ambler, T. and Sytles, C. (1995), "Brand equity: towards measures that matter", PAN'AGRA working paper, London Business School, April.

Amraoui, L. and Morales, D.P. (2006), "Relación entre el Riesgo y la Confianza en la Marca. Estudio Exploratorio en Francia”, Pensamiento y Gestión, No. 20, Julio, pp. 216-237. 
Anderson, J.C. and Gerbing, D.W. (1982), "Some methods for respecifying measurement models to obtain unidimensional construct measurement", Journal of Marketing Research, Vol. 19 No. 4, pp. 453-460.

Ang, S.H. and Lim, E.A.C. (2006), "The influence of metaphors and product type on brand personality perceptions and attitudes", Journal of Advertising, Vol. 35 No. 2, pp. 39-53.

Back, K.-J. (2005), "The effects of image congruence on customers' brand loyalty in the upper middle-class hotel industry", Journal of Hospitality and Tourism Research, Vol. 29 No. 4, pp. 448-467.

Barwise, P. (1993), “Brand equity: snark or boojum?”, International Journal Research Marketing, Vol. 10 No. 1, pp. 93-104.

Biel, A.L. (1993), “Converting image into equity”, in Aaker, D.A. and Biel, A. (Eds), Brand Equity and Advertising: Advertising's Role in Building Strong Brands, Lawrence Erlbaum, Associates, Inc., Hilsdale, NJ, pp. 67-82.

Blackston, M. (1995), "The qualitative dimension of brand equity", Journal of Advertising Research, Vol. 35 No. 4, pp. RC-2-RC-7.

Bollen, K. (1989), A Structural Equation with Latent Variables, Wiley, New York, NY.

Browne, M.W. and Shapiro, A. (1988), "Robustness of normal theory methods in the analysis of linear latent variable models", British Journal of Mathematic Statistic Psychology, Vol. 41, pp. 193-208.

Buil, I., Martínez, E. and Chernatony, L. (2013), "The influence of brand equity on consumer responses", Journal of Consumer Marketing, Vol. 30 No. 1, pp. 62-74.

Calderón, H., Cervera, A. and Mollá, A. (1997), "Brand assessment: a key element of marketing strategy", Journal of Product and Brand Management, Vol. 6 No. 5, pp. 293-30.

Chaudhuri, A. (1995), "Brand equity or double jeopardy?", Journal of Product and Brand Management, Vol. 4 No. 1, pp. 26-32.

Chaudhuri, A. and Holbrook, M.B. (2001), "The chain of effects from brand trust and brand affect to brand performance: the role of brand loyalty", Journal of Marketing, Vol. 65 No. 2, pp. 81-93.

Crimmins, J.C. (2003), "Better measurement and management of brand value", Journal of Advertising Research, Vol. 40 No. 6, pp. 136-144.

Czellar, S. (1997), "Capital de Marque: Concepts, Construits et Mesures", Section des Hautes Etudes Commerciale, Cahier de Recherche No. 97/16, Université de Genève.

Czellar, S. and Dennis, J.E. (2002), "Un Modele Integrateur du Capital Client de la Marque: Une perspective Psycho-Cognitive", Recherche et Applications en Marketing, Vol. 17 No. 1, pp. 43-56.

Dawar, N. and Pillutla, M.M. (2000), "Impact of product-harm crises on brand equity: the moderating role of consumer expectations", Journal of Marketing Research, Vol. 37 No. 2, pp. 215-226.

Diamantopoulos, A. and Siguaw, J.A. (2000), Introducing LISREL - A Guide for the Uninitated, Sage Publications, London.

Erdem, T. and Swait, J. (1998), "Brand equity as a signalling phenomenon”, Journal of Consumer Psychology, Vol. 7 No. 2, pp. 131-158.

Faircloth, J.B., Capella, L.M. and Alford, B.L. (2001), "The effect of brand attitude and brand image on brand equity", Journal of Marketing, Theory and Practice, Vol. 9 No. 3, pp. 61-75.

Farquhar, P.H. (1989), "Managing brand equity”, Marketing Research, Vol. 1 No. 3, pp. 24-33.

Feldwick, P. (1996), "What is brand equity anyway, and how do you measure it?", Journal of Market Research Society, Vol. 38 No. 2, pp. 85-104. 
JFMM 20,4

Hair, J.F., Anderson, R.E., Tatham, R.L. and Black, W.C. (2006), Multivariate Data Analysis, 6th ed., Pearson, Prentice-Hall, Upper Saddle River, NJ.

Irmscher, M. (1993), "Modelling the brand equity concept", Marketing and Research Today, Vol. 21 No. 2, pp. 102-110.

Kapferer, J.N. (1997), Strategic Brand Management: Creating and Sustaining Brand Equity Long Term, 2a ed., Kogan Page, London.

Keller, K.L. (1993), "Conceptualizing, measuring, and managing customer-based brand equity”, Journal of Marketing, Vol. 57 No. 1, pp. 1-22.

Keller, K.L. (2008), Strategic Brand Management, 3rd ed., Prentice Hall, Englewood Cliffs, NJ.

Keller, K.L. and Lehmann, D.R. (2003), "How do brands create value?”, Marketing Management, Vol. 12 No. 3, pp. 26-31.

Kuikka, A. and Laukkanen, T. (2012), "Brand loyalty and the role of hedonic value", Journal of Product and Brand Management, Vol. 21 No. 7, pp. 529-537.

Lassar, W., Mittal, B. and Sharma, A. (1995), "Measuring customer-based brand equity", Journal of Consumer Marketing, Vol. 12 No. 4, pp. 11-19.

Leuthesser, L. (Ed.) (1988), Defining, Measuring and Managing Brand Equity: A Conference Summary, Report No. 88-104, Marketing Science Institute, Cambridge, MA.

Low, G.S. and Lamb, C.W. Jr (2000), "The measurement and dimensionality of brand associations", Journal of Product and Brand Management, Vol. 9 No. 6, pp. 350-368.

Mahajan, V., Rao, V.R. and Srivastava, R.K. (1994), "An approach to assess the importance of brand equity in acquisition decisions", Journal of Product Innovation Management, Vol. 11 No. 3, pp. 221-235.

Motameni, R. and Shahrokhi, M. (1998), "Brand equity valuation: a global perspective”, Journal of Product \& Brand Management, Vol. 7 No. 4, pp. 275-290.

Netemeyer, R.G., Krishnan, B., Pullig, C., Wang, G., Yagci, M., Dean, D., Ricks, J. and Wirth, F. (2004), "Developing and validating measures of facets of customer-based brand equity", Journal of Business Research, Vol. 57 No. 2, pp. 209-224.

Nunnally, J.C. (1978), Psychometric Theory, 2nd ed., McGraw-Hill, New York, NY.

Odin, Y., Odin, N. and Valette-Florence, P. (2001), "Conceptual and operational aspects of brand loyalty. an empirical investigation", Journal of Business Research, Vol. 53 No. 2, pp. 75-84.

Oliver, R. (1999), "Whence consumer loyalty?”, Journal of Marketing, Special Issue - Fundamental Issues and Directions for Marketing, Vol. 63 No. 4, pp. 33-44.

Oliver, R.L. (1997), Satisfaction: A Behavioral Perspective on the Consumer, McGraw-Hill, New York, NY.

Pappu, R., Quester, P.G. and Cooksey, R.W. (2005), "Consumer-based brand equity: improving the measurement - empirical evidence", Journal of Product and Brand Management, Vol. 14 No. 3, pp. 143-154.

Park, C.S. and Srinivasan, V. (1994), "A survey-based method for measuring and understanding brand equity and its extendibility", Journal of Marketing Research, Vol. 31 No. 2, pp. 271-288.

Peterson, R.A. (1994), “A meta-analysis of cronbach's coefficient alpha”, Journal of Consumer Research, Vol. 21 No. 2, pp. 381-391.

Phau, I. and Lau, K.C. (2001), "Brand personality and consumer self-expression: single or dual carriage way?”, Brand Management, Vol. 8 No. 6, pp. 428-444.

Rangaswamy, A., Burke, R. and Oliva, T.A. (1993), "Brand equity and the extendibility of brand names", International Journal Research Marketing, Vol. 10 No. 3, pp. 61-75. 
Simon, C.J. and Sullivan, M.W. (1993), "The measurement and determinants of brand equity: a financial approach", Marketing Science, Vol. 12 No. 1, pp. 28-52.

Srivastava, R.K. and Shocker, A.D. (1991), "Brand equity: a perspective on its meaning and measurement", Working Paper No. 91-124, Cambridge, MA.

Stahl, F., Heitmann, M., Lehmann, D.R. and Neslin, S.A. (2012), "The impact of brand equity on customer acquisition, retention and profit margin", Journal of Marketing, Vol. 76 No. 4, pp. 44-63.

Vázquez, R., del Río, A.B. and Iglesias, V. (2002), "Consumer-based brand equity: development and validation of a measurement instrument", Journal of Marketing Management, Vol. 18 Nos 1-2, pp. 27-48.

Villarejo-Ramos, A.F. and Sánchez-Franco, M.J. (2005), "The impact of marketing communication and price promotion on brand equity", Brand Management, Vol. 12 No. 6, pp. 431-444.

Yoo, B. and Donthu, N. (2001), "Developing and validating a multidimensional consumer-based brand equity scale", Journal of Business Research, Vol. 52 No. 1, pp. 1-14.

Yoo, B. and Donthu, N. (2002), "Testing cross-cultural invariance of the brand equity creation process", Journal of Product and Brand Management, Vol. 11 No. 6, pp. 380-398.

Yoo, B., Donthu, N. and Lee, S. (2000), "An examination of selected marketing mix elements and brand equity", Journal of the Academy of Marketing Science, Vol. 28 No. 2, pp. 197-213.

Zeithaml, V.A. (1988), "Consumer perceptions of price, quality, and value: a means-end model and synthesis of evidence”, Journal of Marketing, Vol. 52 No. 3, pp. 2--22.

\section{Further reading}

Keller, K.L. (2001), "Building customer-based brand equity", Marketing Management, Vol. 10 No. 2, pp. 14-20.

\section{Corresponding author}

Paula Rodrigues can be contacted at: pcristinalopesrodrigues@gmail.com
Perceptual and behavioural dimensions

For instructions on how to order reprints of this article, please visit our website:

www.emeraldgrouppublishing.com/licensing/reprints.htm

Or contact us for further details: permissions@emeraldinsight.com 